\title{
La Sinfonía de Babel [Babel's Symphony]
}

\author{
NICOLÁS ARNÁEZ
}

\begin{abstract}
At its core, the practice of creating sound installations as sonic art involves presenting and manipulating audio in a gallery-like setting. In the case of "La Sinfonía de Babel" the usage of pre-existing musical and literary phrases, or "quoting," formulates the substantive basis for a non-interactive quadraphonic piece that challenges preconceptions of appropriation, citation, and plagiarism where it concerns composition. Inspired by the works "Sinfonia" by Italian composer Luiciano Berio, and "La Biblioteca de Babel" by Argentinian writer Jorge Luis Borges, "La Sinfonía de Babel" recontextualizes conventional ideas of musical narratives by combining and indeterminately presenting excerpts of six hundred and forty looped musical works from different time periods, thus generating a thick and immersive cluster of audio. Within this milieu, auditors are invited to sit and read Borges' text whilst simultaneously identifying musical familiarities within the cluster, hence experiencing quoting on a multi-dimensional level. This paper offers a methodological and aesthetic overview of Berio and Borges' works, focusing specifically on how citation is approached from musical and literary perspectives. Furthermore, structural and technical methodologies are analyzed as a means of better understanding the overarching creative process.
\end{abstract}

Keywords: sound installation, sound art, Borges, Berio, sonorous texture, Max MSP, library, symphony, reading

$\mathrm{I}_{\mathrm{n}}$ this article, I will discuss the creative process behind my original multimedia sound installation La Sinfonia de Babel (2014). This work finds its inspiration in two distinct creative works. The first is Sinfonia for eight voices and orchestra, written in 1968 by Italian composer Luciano Berio. The second work is the short story "La Biblioteca de Babel" (The Library of Babel), written in 1941 by Argentinian novelist Jorge Luis Borges. These works have garnered the interest of musicologists, composers, and mathematical researchers alike, and their commentaries have served as a springboard for some of my own ideas. ${ }^{1}$ Both pieces are based upon the idea of

${ }^{1}$ The research on these works by scholars Michael Hicks (musicologist, Brigham Young University), Miguel Bellusci (composer and professor, Universidad Nacional de Cuyo), Eduardo Plaza (PhD. Music, Universidad Simón Bolivar), Javier Fresán (writer and mathematician, Paris University), Antonio Toca Fernández (researcher and professor, 
a structuring of musical passages or elements by recontextualizing and giving new significance to preexisting artistic creations. In Berio's Sinfonia, diverse passages of music from well-known composers are juxtaposed against each other, resulting in what author Peter Burkholder defines as music, or sound, collage (Burkholder 2001). As he explains, such a collage consists of diverse preexisting pieces or sections of music which are brought together, yet they retain their original characteristics of tonality, timbre, texture, meter and tempo. This results in an absence of the traditional relationships amongst parameters of tonal music, which highlight the individuality of each piece.

In "La Biblioteca de Babel," Borges creates a fictional short story of an imaginary library which holds within it all the books ever written in the history of the world. This massive collection, stored in an endless labyrinth-like structure, is inhabited by diverse characters (librarians, decipherers, pilgrims, etc.), who relate their lives inside the structure, and talk about what they have seen and discovered about the mysterious place during their stay.

The first step towards the realization of my own work was to try to understand how these two works are related, and what makes them similar. In particular, I was interested in how both authors use the idea of quotation and citation, and how the experience of listening to, and reading these works can form the basis for the conception of a new piece.

\section{LUCIANO BERIO - SINFONIA}

Luciano Berio (1925-2003) composed the Sinfonia in 1968. Part III, the movement upon which my sound installation of La Sinfonia de Babel is primarily based, is constructed from a sonic and poetic collage of musical and literary quotations (Bellusci, 2008). Berio writes about its text: "The main text for the third section consists of fragments from Samuel Beckett's The Unnamable, which, in turn, generate a large number of 'daily life' references and quotations” (Berio 2014). Berio's collection of musical quotations for this movement can be described, ultimately, as representing fragments of a historical musical past. In addition to the primary musical quotation - the Scherzo of Mahler's Second Symphony, which functions as a kind of ground bass throughout the movement - one can find layers of musical excerpts

Universidad Autónoma Metropolitana), and myself are presented first, thus contextualizing my new installation by demonstrating the creative methodologies employed by Berio and Borges. Secondly, I describe how specific findings in this research inspired the creation of $L a$ Sinfonía de Babel. Lastly, I explain in detail its particulars, such as content, structure, technical ideations, and performance requirements. 
of composers such as Bach, Beethoven, Brahms, Mahler, Debussy, Ravel, Strauss, Stravinsky, Schoenberg, Berg, Stockhausen, Boulez and also from Berio himself, amongst others (Plaza 2013, 6). Thus, in the words of Eduardo Plaza: "Berio uses the superimposition of anachronistic musical styles which co-exist in the same work and create a hybrid language" (Plaza 2013, 9). Michael Hicks's analysis of this movement shows the remarkable collage of quotations that structure this work (Ex. 1a and b).

As Hicks demonstrates, the vertical axis of the score assembles different fragments, or quotations of music of many composers. Furthermore, the number of quotations which are heard simultaneously changes over time. This idea of musical quotation creates two distinct parameters: 1) the creation of a new significance for the individual excerpts themselves by the use of sonic intertextuality, and 2) an entirely new work based on a musical texture in permanent mutation of familiar sonorities. Hence, the piece moves forward in a kind of compositional coalition between Berio and historical musical works.

\section{JORGE LUIS BORGES-“LA BIBLIOTECA DE BABEL”}

Jorge Luis Borges (1899-1986) wrote "La Biblioteca de Babel" ("The Library of Babel") in 1941 as part of a collection of short stories under the title Ficciones. In "La Biblioteca de Babel," Borges describes an enormous imaginary library whose books contain every possible arbitrary combination of twenty five symbols: the period, the comma, the space, and the twenty two letters of the alphabet (Hendricks 2009, 5). ${ }^{2}$ The result is a library which contains every book that can be written in any language, and in any of the possible combinations of the twenty five characters (Fresán 2007, 134).

Architecturally speaking, Borges describes the layout of the library as methodically arranged in a series of hexagonal rooms, each of which stores a fixed number of books on a fixed number of shelves. The exact number of hexagonal rooms that make up the library is a mystery, as Borges states in the very first sentence: "The universe (which others call the Library) is composed of an indefinite, perhaps infinite, number of hexagonal galleries..." However, Borges describes in detail how the layout of each room is arranged: "Twenty bookshelves, five to each side, line four of the hexagon's six sides; the height of the bookshelves, floor to ceiling, is hardly greater than the height of a normal librarian." Later, he specifies how many books are placed on these shelves: "Each wall of each hexagon is furnished with five

\footnotetext{
${ }^{2}$ Borges does not specify which twenty-two-letter alphabet he refers to, nor have any of the scholars so far encountered offered an explanation for this anomaly.
} 


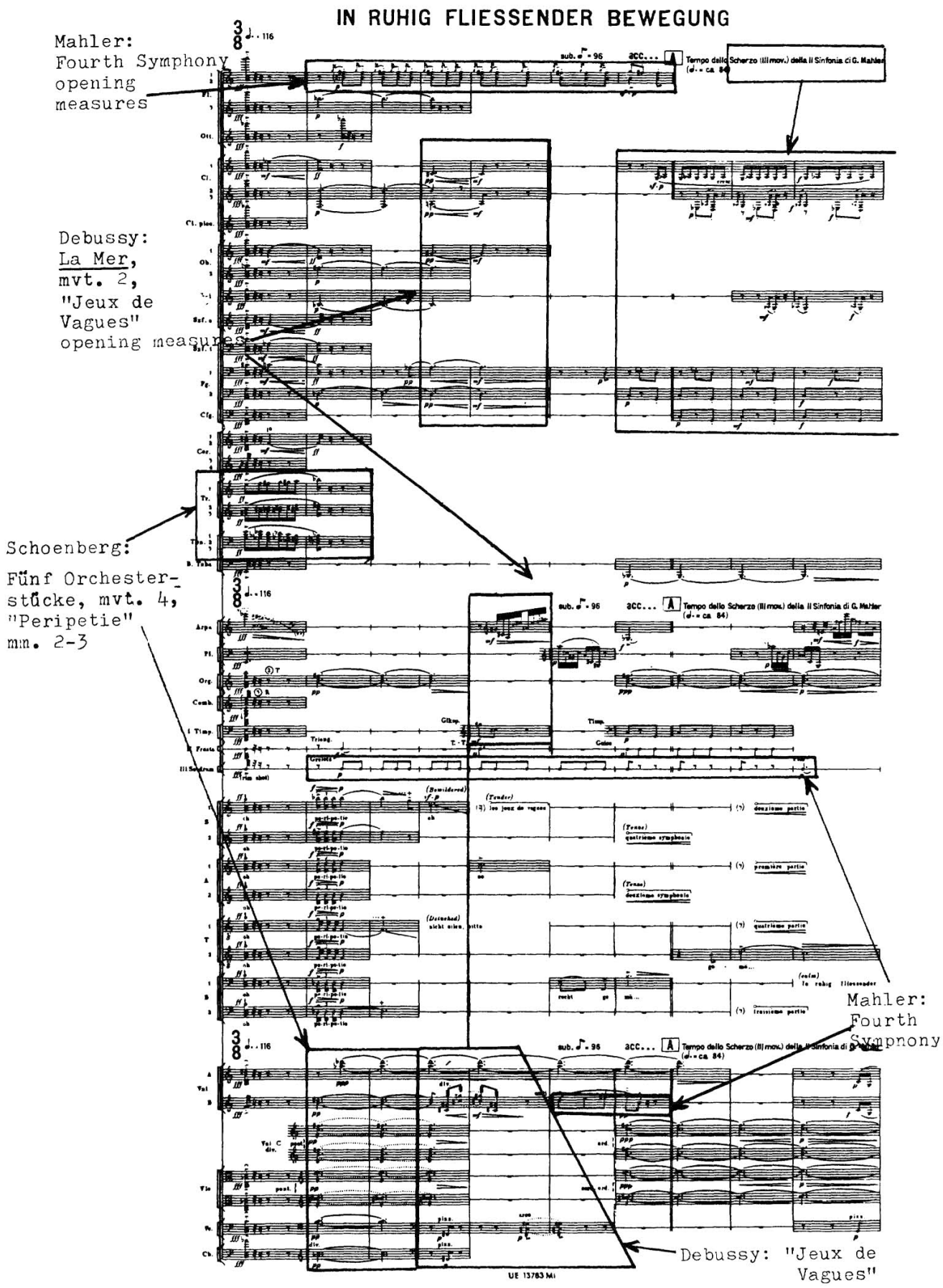

Ex. 1a. Berio, Sinfonia, $3^{\text {rd }}$ movement, measures 1 to 10 (Hicks 1982, 200-201) 


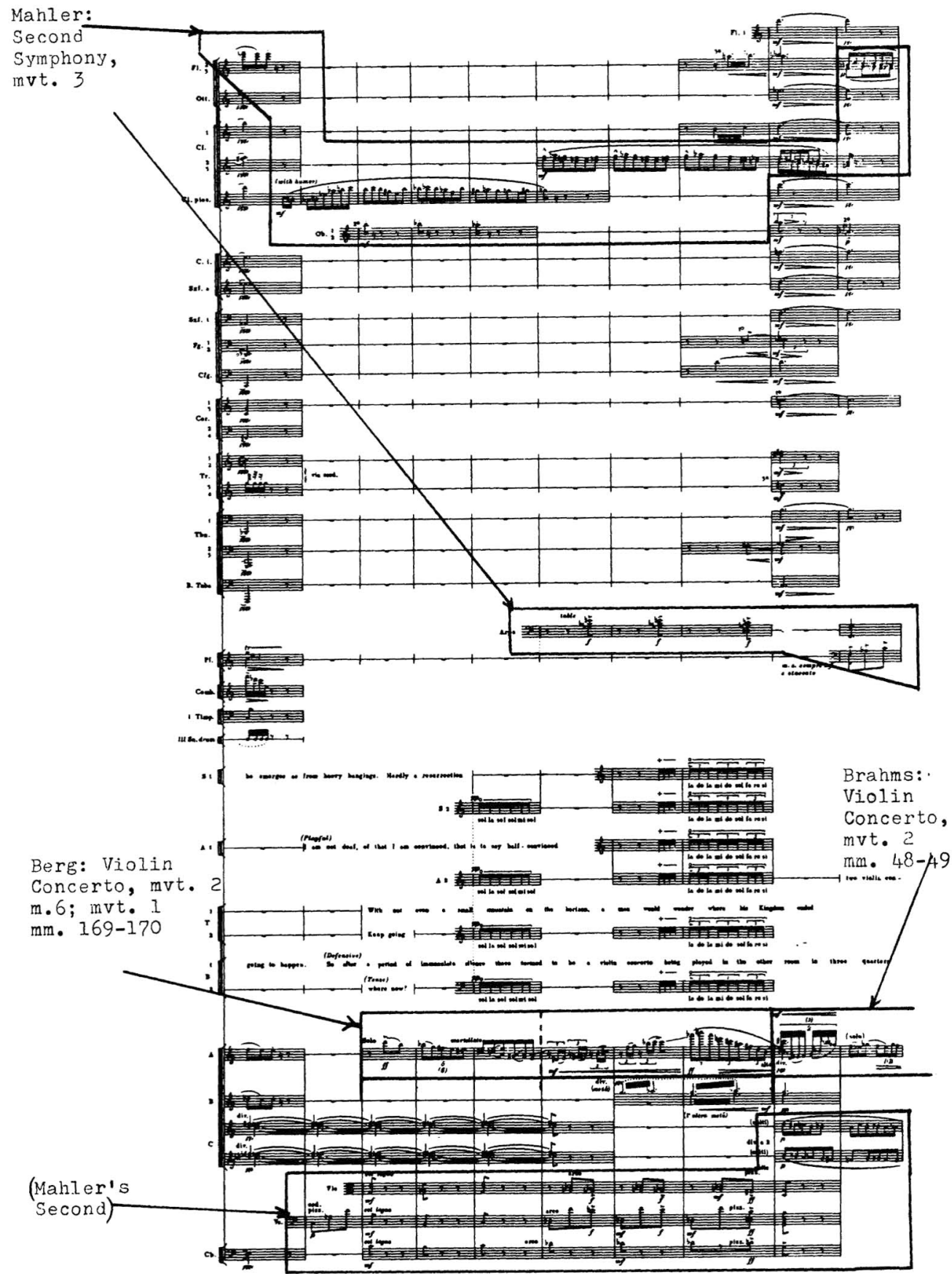

Ex. 1b. Berio, Sinfonia, $3^{\text {rd }}$ movement, measures 59 to 69, (Hicks 1982, 200-201) 
bookshelves; each bookshelf holds thirty two books identical in format [...]" (Borges 1962, 112-113). Finding the exact number of books that are placed in the shelves of each of the library rooms is a matter of logical and mathematical operations:

1. The galleries are hexagonal.

2. Borges states that the shelves cover all the walls except two, which means that just four out of the six sides of the hexagonal room hold books; the other two are passages that leads to other equally distributed rooms (see Fig. 1).

3. On each one of these four walls there are twenty shelves (five shelves per each of the four walls).

4. Each one of these shelves contains thirty two books.

5. By multiplying thirty two (books) by five (shelves), we arrive at the number of books placed in one wall: one hundred and sixty.

6. By multiplying a hundred and sixty (books) by four (walls with books per hexagonal room) we can ascertain exactly how many books are stored in each hexagonal room: six hundred and forty.

Architect Antonio Toca Fernández has proposed a graphic layout that, despite the fact that the drawing is not completely accurate (note the northern walls where six shelves can be counted from bottom to top, instead of five), the general layout is illuminating as it helps one imagine how the library might look. (See Fig. 1.)

\section{LA SINFONIA DE BABEL (BABEL'S SYMPHONY), A MULTIMEDIA \\ INSTALLATION}

Inspirational flow

The first connection I found between Sinfonia and "La Biblioteca de Babel" was the use of the principle of collection and collage, in different but related manners: while Berio composes a musical piece by accumulating fragments of existing music (in addition to a layer of his own writing), Borges describes a place made out of all the literary pieces which have ever existed or will exist. If Borges' library were filled with music instead of books, the sonic result would likely Berio's Sinfonia, Part III, but escalated to an unimaginable level. This is the central premise I used as a creative support for my own undertaking. 


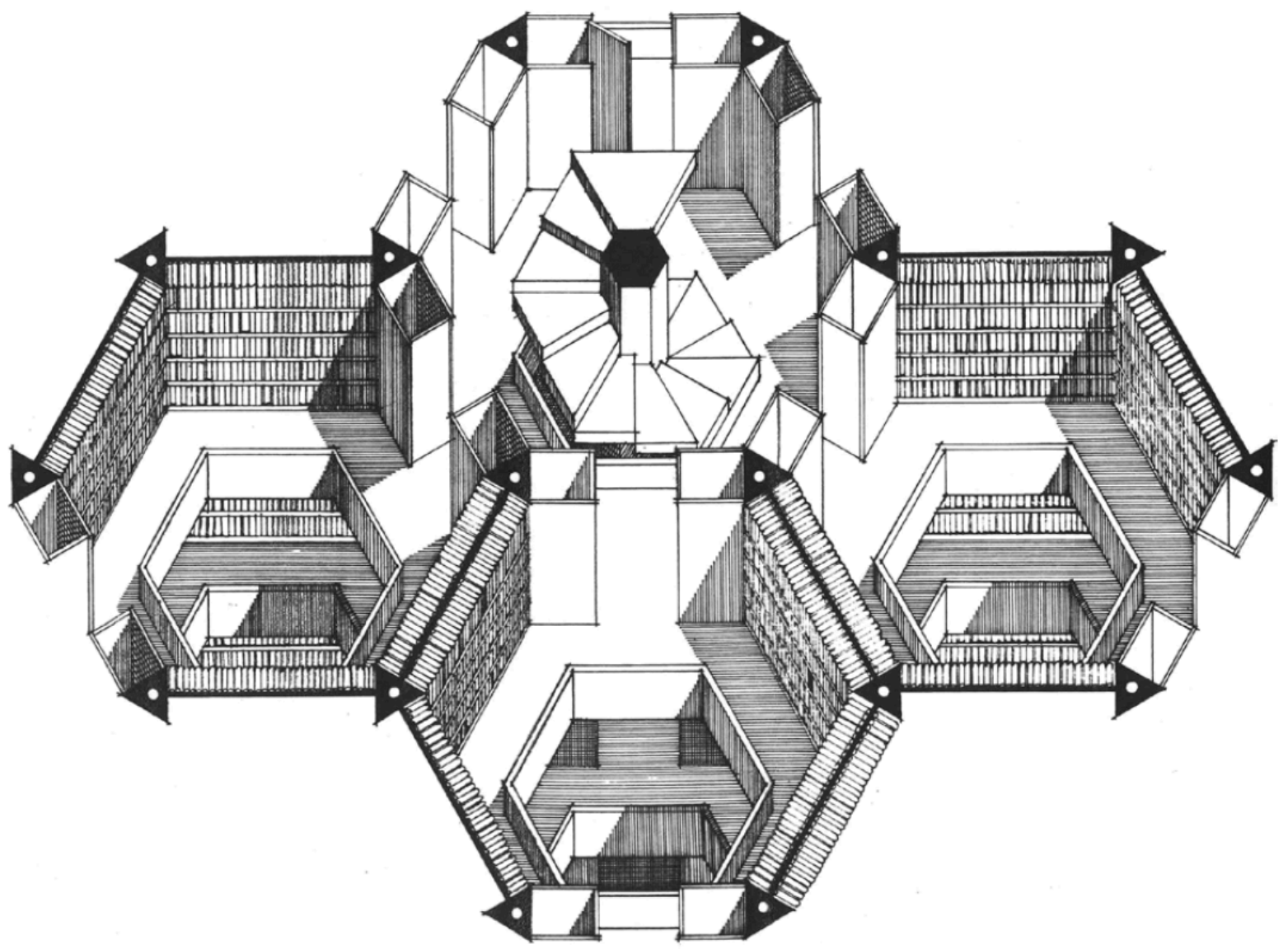

Fig.1. Three connected hexagonal rooms of Babel's library (Toca 2009, 78)

The first challenge was to export ideas from literature to aural expression, and to represent in a sound installation, an imaginary library where combinations of sounds replaced the library of books. The sound installation represents one imaginary hexagonal room of an imaginary sound archive. Each of four speakers inside the room (representing Borges's four walls) reproduce 160 works, thus bringing together in a different configuration the idea of coexisting layers of music, conceived as a simultaneous mass.

\section{Content}

In La Sinfonia de Babel, four speakers are placed in a room, and each speaker plays one hundred and sixty musical pieces (controlled by a computer that runs a Max 7 patch). All one hundred and sixty pieces are collated in terms of specifics such as 
historical period, instrumental type, and composer type: one speaker plays only romantic piano music; a second one plays orchestral music from the nineteenth and twentieth centuries; in a third the complete collection of the Latin jazz player Michel Camilo can be heard; and in the fourth only Renaissance vocal music is represented. However, none of this information is given to the visitor. Each speaker represents one of the four walls of Borges' hexagonal rooms, and each piece represents a book placed on the shelves. The main idea of this archive is to store sound (not scores, nor recordings as such, but sounding music). Since music depends on time to exist, the solution is to create a sound archive capable of storing the acoustic energy produced over time by each piece. Thus, this acoustic energy created by all six hundred and forty musical pieces are presented in a perpetual loop.

A permanent and almost infinite vertical relationship is generated between the pieces represented in each speaker, which results in a constantly changing sonic texture. This textural phenomenon of perpetual aural evolution also occurs as a whole, in the interaction between the four speakers. Thinking further along these lines, the sound installation represents one room out of a quasi-infinity of interconnected hexagons, which extend the sonorous and textural phenomena to an unimaginable scale.

\section{TECHNICAL REQUIREMENTS}

The sound installation La Sinfonia de Babel is conceived for a four-walled room around which four speakers are placed. (A fifth speaker is recommended: a subwoofer that plays the low frequencies of all four speakers. This technical detail is not mandatory). The speakers should be sounding all the time, without any interruption. Ideally, the room should have two entrances. The space should be modified to form a hexagon by using drywall, cardboard, curtains, or similar materials. Each of the four walls has a speaker, leaving the entrances free, as shown in Figure 2.

In the centre of the room, which should be equipped with a table, chairs, couches, or similar pieces of furniture, at least five copies of Borges short story should be available for the visitors. The inscription shown in Figure 3, which functions as a sort of program note, must be added at the end of the Borges short story. 


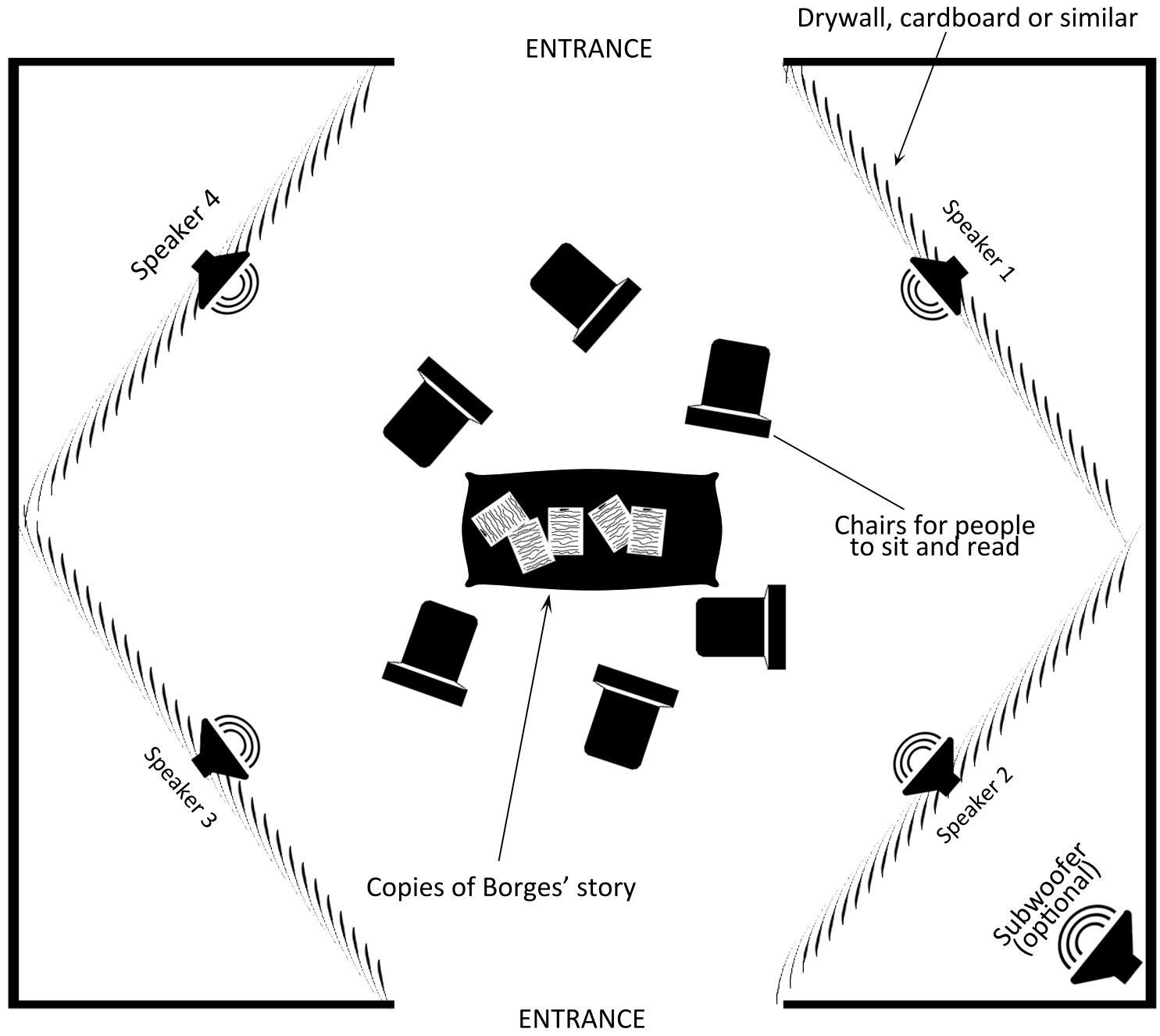

Fig. 2. La Sinfonía de Babel, room layout 
La sinfonía de Babel [Babel's Symphony] Sound Installation Nicolás Arnáez - 2014

The piece you are experiencing now is inspired on Berges' short story you just read: "The Library of Babel" (1941). This sound installation is a on Borges' short story you just read: "The imaginary library like the one in the story interpolations of every book in all books, all books in all instead of storing "all books [...], the result you are listening right now is inspired oll books in all languages" it stores all music. The sonic

The fundamental law of Borges' libiciano Berio "Sinfonia" (1968), III movement. elements: the period, the comma, the twenty "all the books [...] are made up of the same possible combinations of the twenty-odd of the alphabet", giving us "all the music you are hearing is the result of the orthographical symbols". In this sounding library, the to be more explicit, the music stored is the ou three elements: pitches, rhythms and instruments, notes (from $C$ to $B$ in their different rege outcome of all possible combinations of the twelve $128^{\text {th }}$ note) by using different musical instruments nine rhythmic values (from double whole note to

This room is organized similarly to the one in Babel, the

the storage medium: as told, instead of books in Babel, the only difference is the content and speakers, instead of shelves we use electricity. whe store sounding music, instead of walls we use are transformed in four electronic speaks, the five shelves per each one of the four walls sixty per wall) we have hundred and sixty sounding thirty-two books per shelve (a hundred and but two sides are doors, this give us a total of four wusical pieces. The Babel library is hexagonal, this very room you are now a place that stor four walls with shelves that hold books, which makes

Finally: in Babel, there is a hidden six-hundred forty sounding musical pieces. dedicated their life to understand it; some of the Pilgrins wist this almost infinite place. Librarians the vain intention of finding their Vindication" books trying to find the true. Now, do you dare to be Inquisitors looked for years in between the predict the organization of this sounding hexare to be one of them in this installation?, can you organized?....

Fig.3. La Sinfonía de Babel, contextualization program 
Typically, sound installations primarily deal with two principles: sonic energy and spatial conception. The sonic energy delivered in sound installations differs from performed music: there is no distinctive performer, hence the installation allows for continuous sonic reproduction. However, the use of the space in sound installations allows for a complete reconceptualization of performativity within a different field of expression: visitors can observe and appreciate colours, shapes, materials, objects; furthermore, they can "move" through the sonic and visual structure and experience the installation from a multitude of spatial perspectives.

La Sinfonía de Babel responds to the Berio and Borges works by recontextualizing the traditional concepts of sound collage and music quotation to stretch the principle of quotation found in Sinfonia. Furthermore, it absorbs the architectonic structure depicted in Borges' library as a model for a specific spatial setting of aural reproduction. The underlying principles in La Sinfonía de Babel are formulated from both sonic and spatial perspectives, inviting the visitor to experience reading, listening and feeling in an innovative, playful, and challenging manner. Future projects inspired by La Sinfonia de Babel might include: making "interactive" sonic material (for example, offering physical books which once opened, emit sound); adding a visual layer to the installation by reconstructing one of Fernández Toca rooms; creating a performative work based on the principles of the installation. These are endeavours that may take shape in future lives of this work.

A final point of consideration worth mentioning: according to Borges' story, Berio's Sinfonia is already being played in some room of La Sinfonia de Babel and likewise this paper already exists somewhere in "La Biblioteca de Babel."

\section{BIBLIOGRAPHY}

Bellusci, Miguel. 2008. "Luciano Berio Sinfonia, III Mov.” Analysis for composition class. Mendoza, Argentina: University National of Cuyo.

Berio, Luciano. 1969. Sinfonia: For Eight Voices and Orchestra. London: Universal Edition [Score].

Berio, Luciano. 2014. Sinfonia (author's note). Centro Studi Luciano Berio. Webpage consulted on December 16, 2014. Link: http://www.lucianoberio.org/node/1494?1683069894=1.

Borges, Jorge Luis. 1998. "The Library of Babel.” In Ficciones, 112-118. Translated by Andrew Hurley. New York: Penguin. 
Burkholder, J. Peter. 2011. "Collage.” In Grove Music Online. Oxford Music Online. Accessed February 15, 2018. https://doiorg.login.ezproxy.library.ualberta.ca/10.1093/gmo/ 9781561592630 .article.53083.

Fresán Javier. 2007. "De la Biblioteca de Babel a los números normales.” Revista TK 19: $133-139$.

Hendricks, Steven, and Brian L. Walter. 2009. Critical Reading in the Library of Babel. Olympia WA: The Evergreen State Collage.

Hicks, Michael. 1981-1982. "Text, Music, and Meaning in the Third Movement of Luciano Berio's Sinfonia.” Perspectives of New Music 20 (1/2): 199-224.

Plaza, Eduardo F. 2013. Difference and Intertextuality in the Third Movement of Luciano Berio's Sinfonia. Venezuela: Charlex Omar López.

Toca Fernández, Antonio. 2009. "La Biblioteca de Babel: Una Modesta Propuesta." Revista Casa del Tiempo 2 (24): 77-80. 